\title{
IMPLEMENTASI DESAIN KOMUNIKASI VISUAL DALAM PEMBELAJARAN PENDIDIKAN AGAMA ISLAM PADA MASA COVID-19
}

\section{IMPLEMENTATION OF COMMUNICATION DESIGN IN LESSON OF ISLAMIC EDUCATION DURING COVID-19}

\author{
Abdul Chalim \\ Institut Agama Islam Negeri Salatiga, Indonesia \\ Email: abdulchalim57@gmail.com \\ Vivin Devi Prahesti \\ Institut Agama Islam Negeri Tulungagung, Indonesia \\ Email: hestivivin038@gmail.com
}

\begin{abstract}
Abstrak
Penelitian dilaksanakan dilaksanakan di Sekolah Dasar Negeri Ngepanrejo Kecamatan Bandongan Kabupaten Magelang dengan mengambil populasi seluruh siswa siswa kelas 1 sampai 5 dengan jumlah keseluruhan sekitar 221. Metode penelitian ini adalah metode kualitatif deskritif secara sistematis, faktual dan akurat mengenai fakta yang terjadi di sekolah tersebut. Tujuan penelitian ini adalah mengetahui seberapa besar tingkat partisipasi siswa dalam menerima dan memahami materi melalui komunikasi visual yang memaksa mereka untuk tidak melakukan pertemuan tatap muka. Hasil penelitian ini adalah kendala eksternal mempengaruhui penjelasan guru ke siswa yang berdampak pada tingkat pemahaman siswa di kelas dan kendala tersebut seperti sinyal, paket kuota internet dan metode guru. Kendala internal didapatkan dari wali siswa yang kurang peduli dengan kondisi belajar anak di era pandemik.
\end{abstract}

Kata Kunci: desain komunikasi visual, pendidikan agama Islam, pemahaman

\section{Abstract}

This research was conducted in State Elementary School of Ngapanrejo in Bandongan District Magelang Regency with taking all students from grade 1 to 5 with overall 221 students as population. The research method was qualitative description systematically, factually, and accurately concerning the fact that happened in elementary schools. The aim research was that how to know the rate of student participation in accepting and understanding the lesson through visual communication, emphasizing they not to undertaking face-to-face learning. The resulting research was that the external obstacles affect teacher's explanation for students, influencing in understanding rates in the class and the obstacles were the signal, internet quota, and teaching method. The internal obstacles were gained from parents not caring toward students learning during the pandemic.

Keywords: communication design, Islamic education, understanding 
Abdul Chalim \& Vivin Devi Prahesti: Implementasi Desain Komunikasi Visual dalam Pembelajaran Pendidikan Agama Islam pada Masa COVID-19

\section{A. Pendahuluan}

Pandemi COVID-19 merupakan musibah yang terjadi pada seluruh penduduk bumi. Seluruh segmen kehidupan manusia di bumi terganggu. Virus ini disinyalir mulai mewabah pada 31 Desember 2019 di kota Wuhan provinsi Hubey Tiongkok. Saat ini sudah menyebar hampir di seluruh penjuru dunia. Coronavirus adalah keluarga besar virus yang menyebabkan penyakit mulai dari gejala ringan sampai berat. Ada setidaknya dua jenis coronavirus yang diketahui menyebabkan penyakit yang dapat menimbulkan gejala berat seperti Middle East Respiratory Syndrome (MERS) dan Severe Acute Respiratory Syndrome (SARS). Corona virus Disease 2019 (COVID-19) adalah penyakit jenis baru yang belum pernah diidentifikasi sebelumnya pada manusia. Virus penyebab COVID-19 ini dinamakan Sars-CoV-2. Virus corona adalah zoonosis (ditularkan antara hewan dan manusia). Penelitian menyebutkan bahwa SARS ditransmisikan dari kucing luwak (civet cats) ke manusia dan MERS dari unta ke manusia. Adapun, hewan yang menjadi sumber penularan COVID-19 ini masih belum diketahui. ${ }^{1}$

Banyaknya kasus kematian yang disebabkan virus COVID 19 ini sehingga virus ini ditetapkan sebagai virus yang berbahaya karena semakin mudahnya penyebaran kerumunan orang, serta kurangnya pemahaman masyarakat mengenai gejala dan penyebaran COVID 19 yang menyebabkan pemerintah membatasi kegiatan masyarakat termasuk kegiatan belajar. Belajar merupakan suatu proses usaha yang dikerjakan oleh individu agar mendapatkan suatu perubahan tingkah laku yang baru secara menyeluruh, sebagai bagian dari hasil pengalamannya dalam berinteraksi dengan lingkungannya. ${ }^{2}$ Pentingya kegiatan pembelajaran bagi para siswa dan guru sehingga pemerintah tetpa mengadakan kegiatan pembelajaran hanya saa caranya yang berbeda. Pembelajaran dilaksanakan dengna cara tatap muka namun, sekarang dilaksanakan dengan cara yang berbeda yaitu dengan belajar secara daring (dalam jaringan) dengan memanfaatkan kemajuan teknologi.

Kemajuan teknologi saat ini memang menjadikan semua pekerjaan menjadi mudah. Tidak haya dalam bidang pekerjaan perkantoran semata tapi juga bisa dalam kegiatan

\footnotetext{
${ }^{1}$ KEMENKES RI, "Pencegahan dan Pengendalian coronavirus disease (Covid-19) (Jakarta: Dirjen Pencegahan dan Pengendalian Penyakit, 2020), 11

${ }^{2}$ Erna Nur Utami, "Teori Humanistik dan Implementasinya dalam Pembelajaran Pendidikan Agama Islam," Mudarrisuna: Media Kajian Pendidikan Agama Islam, Vol. 10, No. 4 (2020): 571-584
} 
Abdul Chalim \& Vivin Devi Prahesti: Implementasi Desain Komunikasi Visual dalam Pembelajaran Pendidikan Agama Islam pada Masa COVID- 19

pembelajaran. Pembelajaran instruksional adalah adalah sebagai proses pembelajaran yakni proses belajar sesuai dengan rancangan. ${ }^{3}$ Dalam kegiatan pembelajaran tidak bisa dipisahkan dengan namanya komunikasi. Evert M. Rogers mendefinisikan komunikasi sebagai proses yang di dalamnya terdapat suatu gagasan yang dikirimkan dari sumber kepada penerima dengan tujuan untuk merubah perilakunya. Pendapat senada dikemukakan oleh Theo Dore Herbert, yang mengatakan bahwa komunikasi merupakan proses yang di dalamnya menunjukkan arti pengetahuan dipindahkan dari seseorang kepada orang lain, biasanya dengan maksud mencapai beberapa tujuan khusus. Selain definisi yang telah disebutkan di atas, pemikir komunikasi yang cukup terkenal yaitu Wilbur Schramm memiliki pengertian yang sedikit lebih detail. Menurutnya, komunikasi merupakan tindakan melaksanakan kontak antara pengirim dan penerima, dengan bantuan pesan, pengirim dan penerima memiliki beberapa pengalaman bersama yang memberi arti pada pesan dan simbol yang dikirim oleh pengirim, dan diterima serta ditafsirkan oleh penerima. ${ }^{4}$

Komunikasi yang dilakukan dalam melakukan kegiatan pembelajaran saat ini sangat beragam. Akan tetapi, komunikasi yang dilakukan dalam melakukan kegiatan pembelajaran saat ini kebanyakan hanya menggunakan komunikasi biasa seperti anya mengirimkan pesan dengan tulisan tanpa disertai keterangan tentang penjelasan materi. Materi yang komplek dalam pembelajaran PAI membuat para pendidik harus bisa mencari solusi dalam menyampaikan materi degan baik. Adanya teori dan praktek membuat komunikasi visual sangatlah diperlukan dalam melaksankan pembelajaran di saat pandemik saat ini, karena ada beberapa materi yang harus menggunakan contoh supaya siswa bisa mempraktekkan dengan benar sesuai yang diharapkan oleh guru. Hasil observasi menunjukkan bahwa lebih dari 221 (60\%) siswa di SDN Ngepanrejo Bandongan tidak mampu mengenali dan memahami pembelajaran melalui daring system dikarenakan mereka belum terbiasa untuk memegang gadget atau alat penghubung jaringan lainnya, sedangkan hanya $40 \%$ siswa memahami materi yang disampaiakan oleh guru melalui sitem tersebut.

\footnotetext{
${ }^{3}$ Sri Haryati, Belajar dan Pembelajaran Cooperative Learning (Magelang: Graha Merdeka, 2017), 1

${ }^{4}$ Muh. Rizal Masdul, "Komunikasi Pembelajaran," IQRA: Journal Ilmu Kependidikan Keislaman, Vol. 13, No. 2 (2018): 5
} 
Abdul Chalim \& Vivin Devi Prahesti: Implementasi Desain Komunikasi Visual dalam Pembelajaran Pendidikan Agama Islam pada Masa COVID-19

\section{B. Kajian Literatur}

\section{Pengertian Desain Komunikasi Visual}

Desain bisa diartikan sebagai suatu perencanaan dalam menggapai suatu gagasan. Desain adalah penataan atau penyusunan. ${ }^{5}$ Desain bisa diartikan sebagi suatau perencanaan dalam menggapai suatu gagasan.

Komunikasi suatu proses pertukaran ide antara satu pihak dengan pihak yang di mana dalam komunikasi tersebut akan terjadi interaksi satu sama lain yang bisa menimblkan tukar pikiran antara satu orang dengan orang yang lain. Komuikasi bisa diartikan sebagai proses untuk mencapai suatu tujuan. Ada beberapa unsur dalam komunikasi yaitu pemberi pesan, pesan, dan penerima pesan. Jika salah satunya hilang maka tidak bisa dikatakan sebagai komunikasi. ${ }^{6}$ Secara umum komunikasi dapat diartikan sebagai proses penyampain pesan dari komunikator ke orang lain. Menurut Hovland, Janis dan Keley, komunikasi adalah suatu proses melalui seseorang atau komentator menyampaikan stimulus biasanya dalam bentuk kata-kata dengan tujuan mengubah atau membentuk perilaku orang-orang lainnya. ${ }^{7}$ Hakikat komunikasi adalah proses dengan pernyataan antar manusia pernyataan tersebut berubah pikiran atau perasaan seseorang kepada orang lain dengan menggunakan bahasa sebagai alat penyalur.

Terminologi "desain komunikasi visual" terdiri atas tiga satuan kata yaitu desain, komunikasi, dan visual. Ketiga satuan kata pembentuk tersebut mempunyai makna tersendiri. Satuan kata baik desain, komunikasi, maupun visual banyak mempunyai aspekaspek untuk dijelaskan. Terutama dengan perkembangan media saat ini, maka ketiga satuan kata pembentuk tersebut semakin kompleks untuk dipahami. ${ }^{8}$ Desain komunikasi visual pada proses perancangan menggunakan peran penting kreativitas untuk menyampaikan

\footnotetext{
${ }^{5}$ Hery Suharsono, Desain Bordir Inspirasi Motif Tradisonal Jepang, (Jakarta: Granmedia, 2006), 10

${ }^{6}$ Nofrion, Komunikasi Pendidikan Penerapan Teori dan Konsep Komunikasi dalam Pembelajaran (Jakarta: Kencana, 2016), 1

${ }^{7}$ Ricky W. Putra, Pengantar Desain Komunikasi Visual dalam Penerapan Elemen dan Presiden Desain Warna Tipografi Layout Visual Identity Ilustrasi Komik Infografis dari Fisiologis Teori Manga Matrix (Yogyakarta: ANDI, 2020), 2

${ }^{8}$ Sri Wahyuningsih, Desain Komunikasi Visual (Maudra: UTM Press, 2015), 1
} 
Abdul Chalim \& Vivin Devi Prahesti: Implementasi Desain Komunikasi Visual dalam Pembelajaran Pendidikan Agama Islam pada Masa COVID- 19

pesan kepada khalayak melalui visualisasi. ${ }^{9}$ Komunikasi visual yang digunakan untuk mengantisipasi berbagai persoalan, baik persoalan komunikasi sosial maupun komersial.

\section{Ruang Lingkup Komunikasi}

Berdasarkan ruang lingkupnya terdiri atas: ${ }^{10}$

a. Desain komunikasi internal

Komunikasi merupakan jenis interaksi yang berada pada ruang lingkup organisasi, sehingga interaksi yang terjadi hanya pada antar pendek di dalam organisasi itu: 1) vertikal, komunikasi yang terjalin berupa perintah atasan arahan himbauan dan lain-lain; 2) horizontal, komunikasi yang terjadi dapat berupa diskusi Rapat yang dilakukan anggota organisasi yang memiliki posisi sama.

b. Komunikasi eksternal

Komunikasi eksternal merupakan komunikasi yang dilakukan organisasi kepada publik atau masa misalnya program televisi radio atau pameran.

\section{Konsep Pembelajaran PAI}

\section{a. Pengertian Pembelajaran}

Salah satu upaya seorang guru untuk meningkatkan mutu pendidikan adalah penggunaan metode pembelajaran yang tepat dalam menyampaikan materi pembelajaran. Pembelajaran adalah suatu proses di mana seseorang seharusnya dikelola untuk memungkinkan terdapat dalam kondisi-kondisi khusus mampu menghasilkan respon terhadap situasi tertentu. ${ }^{11}$ Pembelajaran adalan aktivitas untuk menjadikan kondisi yang memungkinkan proses belajar siswa yang berangsung secara optimal. ${ }^{12}$ Suatu kombinasi yang meliputi unsur-unsur manusiawi material fasilitas yang saling mempengaruhi untuk mencapai tujuan. Kegiatan pembelajaran harus dilaksanakan dengan cara yang menarik dan bisa menarik perhatian siswa supaya siswa dapat memperhatikan dan memahami materi yang disampaikan oleh guru.

\footnotetext{
${ }^{9}$ Maria Fitriah, Komunikasi Pemasaran Melalui Desain Visual (Sleman: CV. Budi Utama, 2018), 22

${ }^{10}$ Suci R. Mar'ih Koesomowidjoo, Dasar-dasar Komunikasi (Jakarta: Bhuana Ilmu Populer, 2021), 21

${ }^{11}$ Halid Hanavi, et.al., Profesionalisme Guru dalam Kegiatan Pembelajaran di Sekolah (Sleman: CV Budi Utama, 2019), 74

${ }^{12}$ Winastawan \& Ginarto, Pakematik Strategi Pembelajaran Inovatif Berbasis TIK (Jakarta: Elex Media Kompitundo, 2010), 1
} 
Abdul Chalim \& Vivin Devi Prahesti: Implementasi Desain Komunikasi Visual dalam Pembelajaran Pendidikan Agama Islam pada Masa COVID-19

\section{b. Pengertian Pendidikan Agama Islam}

Pendidikan Agama Islam adalah usaha orang dewasa muslim yang bertaqwa secara sadar mengarahkan dan membimbing pertumbuhan serta perkembangan fitrah (kemapuan dasar) anak didik melalui ajaran Islam ke arah titik maksimal pertumbuhan dan perkembangannya. ${ }^{13}$

Muhaimin berpendapat dalam Ratih (2018: 8) bahwa Pendidikan Agama Islam merupakan salah satu bagian dari pendidikan Islam. Istilah "pendidikan Islam" dapat dipahami dari beberapa perspektif, yaitu: a) ilmu pendidikan menurut Islam, suatu konsep, ide, nilai dan norma-norma kependidikan yang diambil, dipelajari dan dianalisis lalu dimunculkan dari sumber pokok ajaran Islam; b) ilmu pendidikan agama Islam, upaya pengembangan secara sistematis sebagaimana proses pendidikan ajaran Islam melalui pembinaan, pembimbingan, dana pelatihan yang dilakukan oleh rang ke orang lain, agar Islam dapat dijadikan sebagai panutan (way of life). ${ }^{14}$

\section{c. Ilmu Pendidikan dalam Islam}

Proses pembudidayaan dan pewarisan pengalaman atau nilai-nilai ajaran Islam yang berlangsung sepanjang sejarah Islam, sejak zaman Nabi sampai sekarang. Pendidikan agama Islam adalah usaha sadar untuk menyiapkan peserta didik dalam meyakini, memahami, menghayati, dan mengamalkan agama Islam melalui kegiatan bimbingan, pengajaran, dan latihan dengan memperhatikan tuntutan untuk menghormati agama lain dalam hubungan kerukunan antar umat beragama dalam masyarakat. Pendidikan dalam Islam menurut Abd Aziz bertujuan untuk meningkatkan keimanan, pemahaman, penghayatan, dan pengalaman siswa tentang agama Islam, sehingga menjadikan manusia muslim yang beriman dan bertakwa kepada Allah SWT serta berakhlak mulia dalam kehidupan pribadi, masyarakat, berbangsa dan bernegara.

\section{d. Tujuan Pendidikan Islam}

Tujuan pendidikan Islam terkait erat dengan tujuan penciptaan manusia sebagai khalifah Allah. Rincian-rincian dari itu telah diuraikan oleh banyak pakar pendidikan Islam. Di antaranya Athiyah al-Abrasyi, mengemukakan rincian aplikasi dari tujuan pendidikan 
Abdul Chalim \& Vivin Devi Prahesti: Implementasi Desain Komunikasi Visual dalam Pembelajaran Pendidikan Agama Islam pada Masa COVID- 19

Islam tersebut: 1) untuk membantu pembentukan akhlak mulia; 2) persiapan untuk kehidupan dunia dan akhirat; 3) menumbuhkan roh ilmiah; 4) menyiapkan peserta didik dari segi professional; dan 5) persiapan untuk mencari rezeki.

Sedangkan menurut Al-'Aththas bahwa tujuan pendidikan menurut Islam bukanlah menghasilkan warga negara dan pekerjaan yang baik, tetapi untuk menciptakan manusia yang baik. Al-'Aththas berpendapat dalam buku Wan Moh Wan Dawud, orang terpelajar adalah orang baik. Baik yang dimaksud adalah adab dalam pengertian yang menyeluruh. Al-'Aththas bersikukuh mengatakan bahwa istilah pendidikan Islam yang paling tepat adalah ta'dib. Ta'dib menurut beliau melibatkan hal-hal berikut: 1) suatu tindakan untuk mendisiplinkan jiwa dan pikiran; 2) pencarian kualitas dari sifat-sifat jiwa dan pikiran yang baik; 3) prilaku yang benar dan sesuai (berlawanan dengan prilaku salah dan buruk); 4) ilmu yang dapat menyelamatkan manusia dari kesalahan dalam mengambil keputusan dan sesuatu yang tidak terpuji; 5) pengenalan dan pengakuan kedudukan (sesuatu) secara benar dan tepat; 6) sebuah metode mengetahui yang mengaktualisasikan kedudukan sesuatu secara benar dan tepat; dan 7) realisasi keadilan sebagaimana direfleksikan oleh hikmah.

Pendidikan dalam konteks ini adalah seperangkat metode dan sarana transformasi nilai pemikiran, nilai-nilai sosial kemasyarakatan, nilai-nilai ilmiah dan uji coba yang dipergunakan oleh ulama, pendidikan untuk mendidik setiap individu, masyarakat, dan manusia seluruhnya dengan tujuan untuk merealisasikan ketakwaan dan takut kepada Allah. Pendidikan Islam memiliki tujuan untuk mengarahkan manusia khususnya umat Islam menjadi pribadi yang beradab, bertakwa juga bernilai di hadapan Allah.

\section{e. Implementasi Desain Komunasi Visual Dalam Pembelajaran PAI}

Situasi pandemi COVID-19 menyebabkan semua serba terbatas dalam bidang apapun, baik di bidang ekonomi, sosial, agama, maupun kegiatan pembelajaran. Seperti yang tercantum dalam undang-undang pasal 30 ayat 1 , di mana setiap anak berhak untuk memperoleh pendidikan. Dengan mejuwudkan hak anak menurut undang-undang pasal 30 ayat 1 tersebut. Maka dari itu, pihak Kemendikbud memutuskan untuk tetap melaksnakan pembelajaran dengan model yang berbeda yaitu dengan cara menggunakan pembelajaran jarak jauh atau sering disebut dengan pembelajaran daring (dalam jaringan). Dalam pembelajaran seperti ini pihak sekolah harus tetap berkomunikasi dengan cara yang 
berbeda yaitu menggunakan media elektronik. Penggunaan pembelajaran elektronik dalam pembelajaran sebenarnya sudah dilaksanakan di negara-negara maju. Akan tetapi, di negara Indonesia bisa dibilang ini adalah hal yang baru, sehingga perlu penyesuaian yang memerlukan waktu tidak sedikit. Media elektronik yang familiar bagi masyarakat umum di lingkungan SDN Ngepanrejo pada saat ini adalah WhatsApp, sehingga para tenaga pendidik dalam melaksanakan pembelajaran hanya menggunakan WhatsApp saja. Selain familiar di masyarakat, aplikasi satu ini juga tidak memerlukan paket data internet terlalu banyak sehingga bisa menghemat kuota internet dibanding dengan aplikasi lain seperti zoom, google meet atau yang lain. Dalam melaksanakan pembelajaran mata pelajaran Pendidikan Agama Islam guru mengirimkan tugas dan menjelaskan melalui group WhatsApp setiap kelasnya.

\section{Metode Penelitian}

Kegiatan penelitian ini menggunakan pendekatan kualitatif yang mana memeroleh data secara langsung dilakukan dengan menganalisis pemahaman siswa dan tingkah laku siswa terhadap pembelajaran dalam jaringan. Penulis mengambil penelitian di SDN Ngepanrejo Bandongan tahun pelajaran 2020/2021 bulan Juli 2020. Populasi penelitian ini adalah seluruh kelas 1 sampai 5 dengan jumlah siswa perkiraan 221 siswa dan menggunakan teknik sampling dalam pengambilan data menggunakan observasi dan studi dokumen.

Metode tersebut menggunakan observasi tidak terstruktur yang terjadi di lapangan dimana peneliti melakukan observasi sesuai perilaku mereka dan hasil belajar mereka terhadap seluruh siswa, sedangkan studi dokumen dilakukan ketika peneliti menganalisis dokumen penilaian mereka yang telah dilakukan oleh guru.

\section{Hasil dan Pembahasan}

Hasil penelitian disajikan dalam bentuk tabel berdasarkan nilai kognitif siswa dalam memahami materi sesuai aspek yang telah ditentukan oleh guru melalui metode komunikasi visual di pembelajaran pendidikan Agama Islam di era pandemik. 
Tabel 1. Skor Kemampuan Siswa Mengerjakan Soal pada Pembelajaran Agama Islam Kelas 1 sampai 5

\begin{tabular}{cccccc}
\hline \multirow{2}{*}{ No } & \multirow{2}{*}{ Kelas } & \multicolumn{5}{c}{ Skor } \\
\cline { 3 - 6 } & I & A & B & C & D \\
\hline 1. & 17 & 6 & 4 & 4 \\
2. & II & 14 & 5 & 4 & 4 \\
3. & III & 21 & 9 & 6 & 4 \\
4. & IV & 33 & 11 & 8 & 7 \\
5. & V & 22 & 7 & 6 & 5 \\
\hline \multicolumn{2}{r}{ Jumlah } & 48 & 40 & 31 & 23 \\
\hline
\end{tabular}

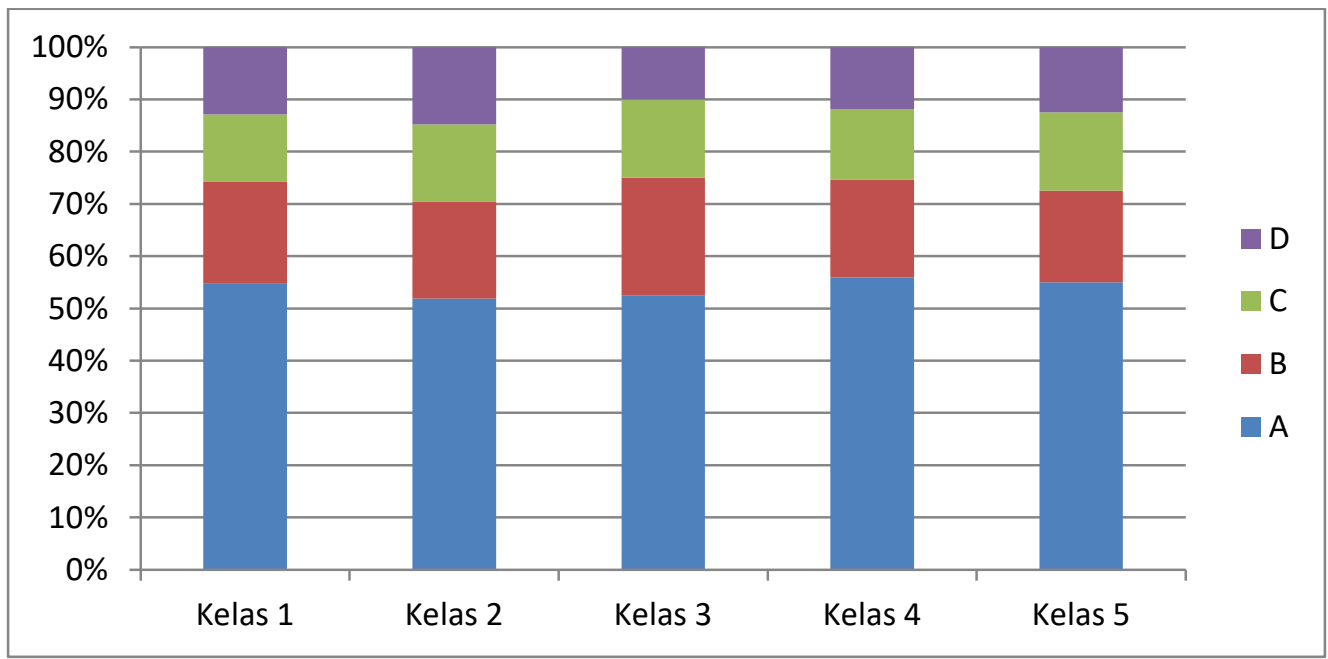

\section{Gambar 1. Tingkat Partisipasi Siswa dalam Mengumpulkan Tugas}

Keterangan:
A: Selalu mengerjakan tugas
B: Kadang-kadang mengerjakan tugas minimal 5 kali dalam seminggu
C: Mengerjakan tugas minimal 2 dalam seminggu
D: Pernah sekali mengerjakan tugas

Secara analisis teoritikal membuktikan bahwa meskipun nilai siswa rata- rata yang mendapat nilai A hampir 60\%, mereka belum memaknai pembelajaran tersebut, dan sisa dari mereka mendapat nilai B perkiraan 20\%, C sebanyak 15\% dan D hanya terhitung sekitas 5\%. Secara praktikal bagi $40 \%$ siswa memahami materi yang diberikan oleh guru, tetapi $60 \%$ dari mereka mengalami kesulitan dalam belajar dengan berbagai kendala. 
Abdul Chalim \& Vivin Devi Prahesti: Implementasi Desain Komunikasi Visual dalam Pembelajaran Pendidikan Agama Islam pada Masa COVID-19

Pada penugasan di pembelajaran PAI, guru memberikan tugas hanya melalui messangger/WhatsApp sehingga banyak siswa mengalami kendala pemahaman mata pelajaran yang telah diampu, bahkan meski nilai mereka mencukupi untuk syarat kelulusan tetapi mereka tetap belum memahami secara maknawi dari pembelajaran yang ditugaskan oleh guru.

\section{E. Simpulan dan Saran}

Sesuai dengan hasil analisis data di atas bahwa siswa yang menggunakan komunikasi visual melalui WhatsApp atau messangger tidak bisa mengakses dengan lancer, karena orang tua tidak memahami teknologi informasi. Tambahannya, kesadaran orang tua dan siswa dalam dunia pendidikan kurang dipentingkan, sehingga mereka lalai dalam menggunakan media visual seperti WhatsApp atau messangger.

Selama pandemik, ketersediaan paket data akan membantu siswa dalam belajar, tetapi kenyataannya hal tersebut disalahgunakan oleh orang tua siswa. Selain itu, kendala sinyal akan mempengaruhi cepat lambatnya siswa mengumpulkan tugas yang telah diberikan oleh guru sehingga hanya sekitar $40 \%$ saja siswa benar-benar paham terkait konsep materi pembeljaran.

Sesuai dengan simpulan di atas, maka sebagai guru sebaiknya menggunakan beberapa alternatif media pembelajaran yaitu melalui home visit karena tidak semua wali atau siswa paham terhadap pembelajaran, oleh karena itu perlunya kunjungan guru ke sekolah untuk memahamkan siswa terkait ,ateri yang telah diajarkan.

Sebagai wali siswa sebaiknya siswa ditanamkan pembelajaran dengan memerhatikan keadaan siswa, dan mereka menjadi guru di rumah sebagai supporting system bagi anak mereka. Bagi wali seyogyanya menggunakan paket data dengan sebaikbaiknya untuk kesejahteraan anak. Berdasarkan penelitian tersebut maka penelitian menemukan persamaan dengan penelitian sebelumnya terkait menggunakan metode pembalajaran agama, tetapi penelitiannya terjadi selama COVID-19. Oleh karena itu, ada perbedaaan metode di setiap pembelajarannya khususnya pembalajaran agama Islam. 
Abdul Chalim \& Vivin Devi Prahesti: Implementasi Desain Komunikasi Visual dalam Pembelajaran Pendidikan Agama Islam pada Masa COVID- 19

\section{F. Daftar Pustaka}

Fitriah, Maria. Komunikasi Pemasaran Melalui Desain Visual. Sleman: CV. Budi Utama, 2018.

Hanavi, Halid, et.al. Profesionalisme Guru dalam Kegiatan Pembelajaran di Sekolah. Sleman: CV Budi Utama, 2019.

Haryati, Sri. Belajar dan Pembelajaran Cooperative Learning. Magelang: Graha Merdeka, 2017.

KEMENKES RI. "Pencegahan dan Pengendalian coronavirus disease (Covid-19)." Jakarta: Dirjen Pencegahan dan Pengendalian Penyakit, 2020

Koesomowidjo, Suci R. Mar'ih. Dasar-dasar Komunikasi. Jakarta: Bhuana Ilmu Populer, 2021.

Masdul, Muh. Rizal. "Komunikasi Pembelajaran." IQRA: Journal Ilmu Kependidikan Keislaman, Vol. 13, No. 2 (2018): 5.

Nofrion. Komunikasi Pendidikan Penerapan Teori dan Konsep Komunikasi dalam Pembelajaran. Jakarta: Kencana, 2016.

Putra, Ricky W. Pengantar Desain Komunikasi Visual dalam Penerapan Elemen dan Presiden Desain Warna Tipografi Layout Visual Identity Ilustrasi Komik Infografis dari Fisiologis Teori Manga Matrix. Yogyakarta: ANDI, 2020.

Suharsono, Hery. Desain Bordir Inspirasi Motif Tradisonal Jepang. Jakarta: Granmedia, 2006.

Utami, Erna Nur. "Teori Humanistik dan Implementasinya dalam Pembelajaran Pendidikan Agama Islam.” Mudarrisuna: Media Kajian Pendidikan Agama Islam, Vol. 10, No. 4 (2020): 571-584.

Wahyuningsih, Sri. Desain Komunikasi Visual. Maudra: UTM Press, 2015.

Winastawan \& Ginarto, Pakematik Strategi Pembelajaran Inovatif Berbasis TIK. Jakarta: Elex Media Kompitundo, 2010. 